\title{
Power Flow Management in Photovoltaic Energy System Using Multiport DC-DC Converter
}

\author{
Sarab AL-CHLAIHAWI, Ameer H. ALI and Mohammed A.T. ALRUBEI \\ inj.srb@atu.edu.iq,inj.ame7@atu.edu.iq andinj.moh3@atu.edu.iq \\ Najaf Technical Institute, Al-Furat Al-Awsat Technical University, 31001 Al-Najaf, Iraq.
}

\begin{abstract}
In this paper, the power flow controller for multi-port DC-DC converter was modified, so it mediator a photocell, a storage element and an isolated load. The MOSFET switches are used to design the presented model to manage the flowing power of load voltage and two sources independently. Theoretical researches are implemented to prove the capability of the controllers to regulate the flowing of power for the photovoltaic generator and the storage element while maintaining the load in three cases. First, the photovoltaic power is greater, less and equal to load resistance and maintaining the switches in the best condition for each case. Finally, the power of the photovoltaic generator follows the direction proposed by the MOSFEST switcher's control.
\end{abstract}

Keywords: Multiport converter, DC-DC Converter, Matlab Simulink, PV Panel, storage element.

\section{Introduction}

In recent years, the renewable energies have become a significant part of power generation because the power demand has been increased very huge levels due to growth of population and industry; three-port converters it used in wind turbines or solar cells connected to the input port that is considered as renewable energy scenarios [1]. The photovoltaic solar energy is a primary and renewable energy source that is fastest growing and is unlimited, clean and free. The integrated multiport DC-DC converters for interfacing photovoltaic power sources and storage batteries are widely used and discussed. These converters present dynamic performance due to centralizes control of power integration and it has the advantages including less components, lower cost, economical, reliable and better dynamic performance [2]. Due to the advantages of the configuration of multiport converters, it has been used in different applications such as interface with a renewable energy source as shown in the survey presented in [3]. Comparative dynamic analysis of different multiport converters including a Dual Input Single Output converter without a transformer, a Three-Port Full and Half-Bridge converters, with transformer isolation for interfacing the renewable energy sources such as photocell along with the energy storage devices. This includes a discussion on their topology, the relationship between inputs and output voltages and the duty cycle of different switches used in these converters [4].

In this paper, we modify the controller of the power flow three-port converter which mediator a photocell, a storage element and an isolated load. Two sources applied in the DCDC converter and the switches (MOSFETs) used to control the flow of power in the converter. The three-port converter interfaces with the photocell, bidirectional storage element and isolated load by a transformer. The main multi-port converter (MPC) advantages are simplified circuit and centralized control and developed with a power management system. Moreover, the MPC 
has two switching legs, the first leg is a unidirectional port connected to the photovoltaic generator source and the second leg is a bidirectional port connected to the battery source [5]. Theoretical studies are implemented to confirm that the controllers are able to regulate the power flows of the photovoltaic generator and the storage element while preserving the load in three cases. First, the photovoltaic power is greater, less and equal to load resistance and maintaining the switches in best condition for each case. Finally, the power of the results of the photovoltaic generator follows the direction proposed by the MOSFEST switcher's controller. The remnant of this paper is coordinated as follows: Section 2 explains the modelling of PV system. Section 3 looks over full-bridge multi-port converter, controller design and the mode of operation for the full-bridge multi-port converter. Finally, conclusions of the work are uncovered in Section 4.

\section{MODELLING OF PV SYSTEM}

The PV equivalent circuit can be modeled by putting the current source and diode in parallel and two parasitic resistances, as illustrated in Figure 1. Basically, the current source of PV cell device and output current are directly proportional to sun light falling on the cell [6].

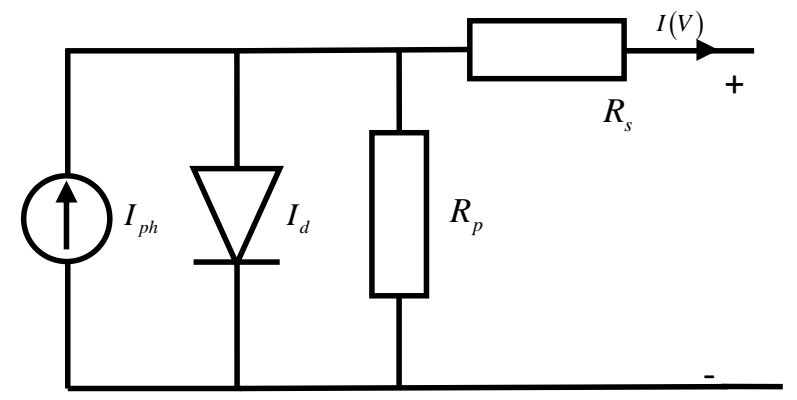

Fig. 1 The equivalent PV cell circuit

The equation of output current-voltage of solar cell is offered as follow:

$$
I_{p v}=I_{p h}-I_{0}\left[\exp \left(\mathrm{q} \frac{V_{P V}+I_{P V} \cdot R_{s}}{n K T}\right)-1\right]-\frac{V_{P V}+I_{P V} \cdot R_{s}}{R_{P}}
$$

The photovoltaic device is characters by its datasheets such as open-circuit voltage, short circuit current, photocurrent, reverse saturation current etc.

\subsection{Voltage of open circuit:}

The voltage of the open circuit $\left(\mathrm{V}_{\mathrm{OC}}\right)$ represents the maximum voltage that a PV panel can provide across its terminals. This voltage is theoretically generated when the terminals of the $\mathrm{PV}$ panel are open. In ideal conditions, the $\mathrm{V}_{\mathrm{OC}}$ can be representing using equation below

$$
V_{o c}=\frac{n K T_{r e f}}{q} \ln \left(\frac{I_{L}}{I_{0}}+1\right)
$$


In this equation, $\mathrm{n}$ represents diode ideality factor, $\mathrm{K}$ denotes the Boltzmann constant (i.e. $1.381 \times 10-23 \mathrm{~J} / \mathrm{K}$ ), $\mathrm{q}$ is the charge value on one electron (i.e. $1.602 \times 10-19 \mathrm{C}$ ), $\mathrm{I}_{\mathrm{L}}$ is the photogenerated current, as mentioned before, $\mathrm{I}_{\mathrm{o}}$ is the saturation current of the diode and $\mathrm{T}_{\text {ref }}$ is used to denote the temperature of solar cell junction.

\subsection{Photo-generated current (Radiation):}

$$
I_{p h}=\left[I_{L-r e f}+\alpha_{I S C}\left(T_{C}-T_{r e f}\right)\right] \frac{G}{G_{r e f}}
$$

$\mathrm{I}_{\mathrm{L}}$ is the photo-generated current, which is generated when the light photons are absorbed by the panels to generate electron-hole pair. $\mathrm{I}_{\mathrm{L}-\mathrm{ref}}$ is the photo-generated current under standard conditions equal to $0.15 \mathrm{~A}$.

$\mathrm{T}_{\mathrm{C}}$ represents the standard temperature of the module, equal to $298 \mathrm{~K}, \alpha \mathrm{I}_{\mathrm{SC}}$ denotes the temperature coefficient of short-circuit current which has the unit of $\mathrm{A} / \mathrm{K}=0.0065 / \mathrm{K}$.

\subsection{Current of reverse saturation:}

The current of reverse saturation $I_{0}$ is the current which measures the leakage of charge carriers (i.e. electrons and holes) across the created p-n junction in reverse bias.

$$
\begin{aligned}
I_{\mathrm{o}} & =\boldsymbol{I}_{\mathrm{o} r}\left(\frac{\boldsymbol{T}}{T_{r}}\right)^{3} e^{\left[\frac{q}{n K N}\left(\frac{E_{g}\left(T_{r}\right)}{T_{r}}-\frac{E_{g}(T)}{T}\right)\right]} \\
I_{0 r} & =\frac{I_{s c n}}{\exp \left(\frac{V_{o c}}{n N V_{T}}\right)}
\end{aligned}
$$

Where, $I_{o}$ the saturated current, $I_{o r}$ the reverse saturation current and the EG is the bandgap constant which for silicon $1.10 \mathrm{Ev}$.

\subsection{Current of Short circuit}

The current of short circuit $\left(\mathrm{I}_{\mathrm{SC}}\right)$ represents the theoretical maximum current that the PV panel can provide; it is the current that flows out of the PV source when its terminals are shorted out. This current can be estimated by the photo-generated current $\mathrm{I}_{\mathrm{L}}$. The short current is calculated using the equation as follows:

$$
I_{s c}=I_{p h}-I_{0}\left[\exp \left(\mathrm{q} \frac{I_{s c} \cdot R_{s}}{a N_{s} V_{t h}}\right)-1\right]
$$

\subsection{Photovoltaic design parameters}

The parameters which are used in the design specification of PV panels used in our Simulink model are shown in table 1. the parameters are displayed in the Simulink environment, 
containing different fields and options for PV panels. The current view enshrines our used parameters in the model. As seen, the model uses a single solar power API-150 module for simulations, which generates a maximum power of $150.075 \mathrm{~W}$. Figure 2 presents the configuration of the solar cell under the Simulink package. The tracking scenario is the ability to track until arriving at the maximum power point with enhancements in transient and steadystate responses of power output illustrated by overshoot, speed and oscillation[7]. various methods presented to calculate an available maximum power from the photovoltaic panel in [11]-[14].

Table 1. Datasheet parameters of Photovoltaic generator.

\begin{tabular}{ll}
\hline Parameters & Value \\
\hline Maximum power & 150.075 Watts \\
Cell number & 72 \\
Open circuit voltage & $41.8 \mathrm{~V}$ \\
Maximum voltage & $34.5 \mathrm{~V}$ \\
Short circuit current & $5.05 \mathrm{~A}$ \\
Maximum current & $4.35 \mathrm{~A}$ \\
Light generated current & $5.0831 \mathrm{~A}$ \\
Reverse saturation current & $1.4617 \mathrm{e}-10 \mathrm{~A}$ \\
Diode idealist factor & 0.93584 \\
Shunt resistance & $69.2646 \Omega$ \\
Series resistance & $0.45367 \Omega$ \\
\hline
\end{tabular}

\begin{tabular}{|c|c|c|}
\hline Block Parameters: $150 \mathrm{~W}$ PV panel & & \\
\hline \multicolumn{2}{|l|}{ Advanced } & \\
\hline \multicolumn{2}{|l|}{ Array data } & Display $I-V$ and $P-V$ characteristics of ... \\
\hline \multicolumn{2}{|l|}{ Parallel strings } & one module @ 25 deg.C \& specified irradiances \\
\hline \multicolumn{2}{|l|}{1} & \\
\hline \multicolumn{2}{|l|}{ Series-connected modules per string } & Ifradiances (W/mL2) $\left[\begin{array}{llll}1000 & 150 & 500 & 250\end{array}\right]$ \\
\hline \multicolumn{2}{|l|}{1} & Plot \\
\hline \multicolumn{2}{|l|}{ Module data } & Model parameters \\
\hline \multicolumn{2}{|c|}{ Module: Advance Solar Hydro Wind Power API-150 } & Light-generated current IL (A) \\
\hline Maximum Power (W) & Cells per module (Ncell) & 5.0831 \\
\hline 150.075 & ${ }^{2}$ & Diode saturation current IO (A) \\
\hline Open circuit voltage $\operatorname{Voc}(\mathrm{V})$ & Short-circuit current Isc (A) & $1.4617 \mathrm{e}-10$ \\
\hline 41.8 & 5.05 & Diode ideality factor \\
\hline \multirow{2}{*}{ Voltage at maximum power point $\mathrm{Vmp}(\mathrm{V})$} & \multirow{2}{*}{ Current at maximum power point $\operatorname{Imp}(A)$} & 0.93584 \\
\hline & & Shunt resistance Rsh (ohms) \\
\hline 34.5 & 4.35 & 69.2646 \\
\hline Temperature coefficient of Voc (\%/deg.C) & Temperature coefficient of Isc (\%/deg.C) & Series resistance Rs (ohms) \\
\hline-0.356 & 0.07 & 0.45367 \\
\hline
\end{tabular}

Fig. 2 Photovoltaic design under Simulink 

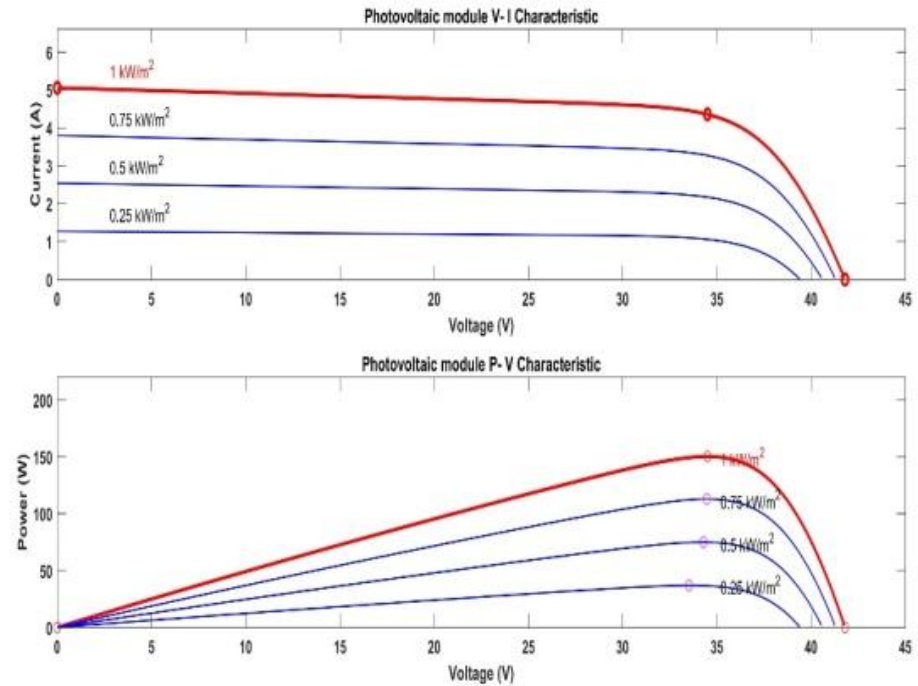

Fig. 3 VI and PV curves for varying radiance

The typical I-V and P-V curves of the photocells are drawn using 72 cells connected in series in Simulink for fixed temperature. As the IR-radiance is varied from $0.25 \mathrm{~kW} / \mathrm{m} 2$ to $1 \mathrm{~kW} / \mathrm{m} 2$, the curves obtained are shown in Figure 3. Similarly, as the temperature conditions are varied while the radiance is held static, the curves obtained for I-V and P-V are illustrated in Figure 4.

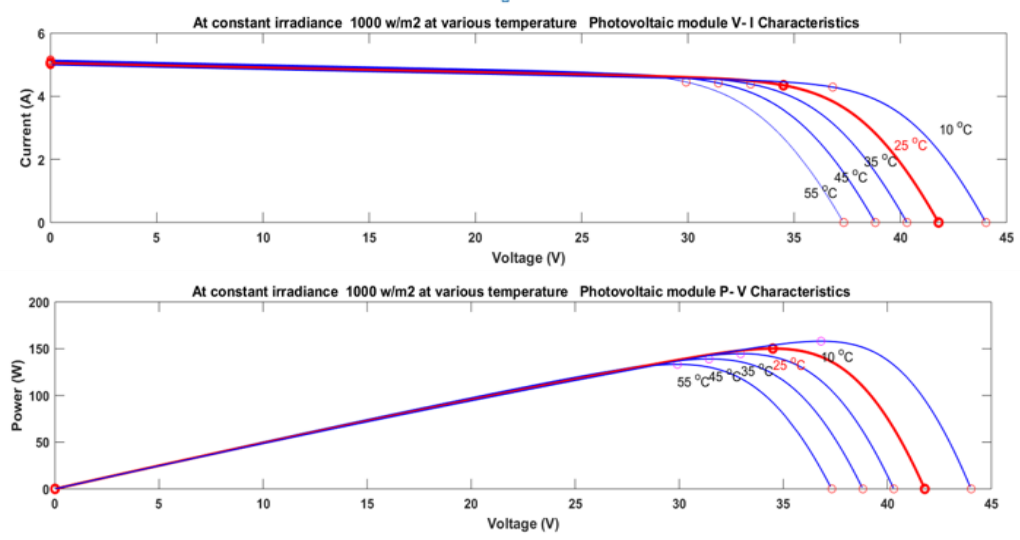

Fig. 4 VI and PV curves for varying temperature

\section{FULL BRIDGE MULTIPORT CONVERTER}

The presented power management system based MPC has designed with a full-bridge converter as shown in Figure 5. The output port of MPC is isolated with a transformer winding such as 
primary winding is connected across with two leg switching converter and the secondary winding is connected with diode rectifier [8]-[10]. The MPC is operated under three modes as follows: in the first one, PV generated power is greater than load demand while the second one is lesser than load demand and the third one is equal to load demand.

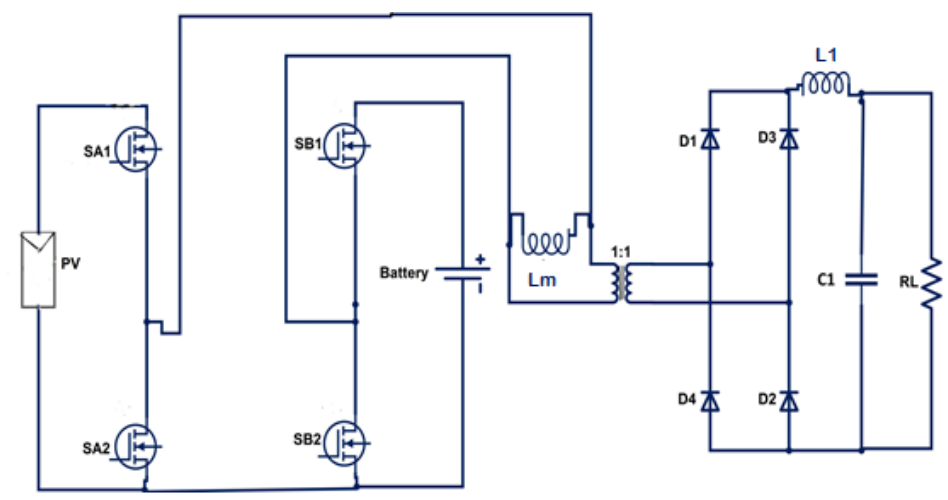

Fig. 5 Full Bridge Three port converter

\subsection{Controller Design}

The power flow management has been designed in such a way that the converter works in three various modes, depending on conditions at the PV source and the load. This controller is designed in Simulink and can make intelligent decisions to turn OFF or ON certain switches according to the present conditions. This is shown in Figure 6. This controller has two inputs such as input one from PV power and input two from load demand. Further, the controller has three outputs such as input 1 is greater than input 2 in this condition output 1 generate positive signal other output signal does not generate any signal. Input 1 is lesser than input 2 in this condition output 2 generates positive signal other output signal does not generate any signal. Input 1 is equal to input 2 in this condition output 3 generates positive signal other output signal does not generate any signal. 


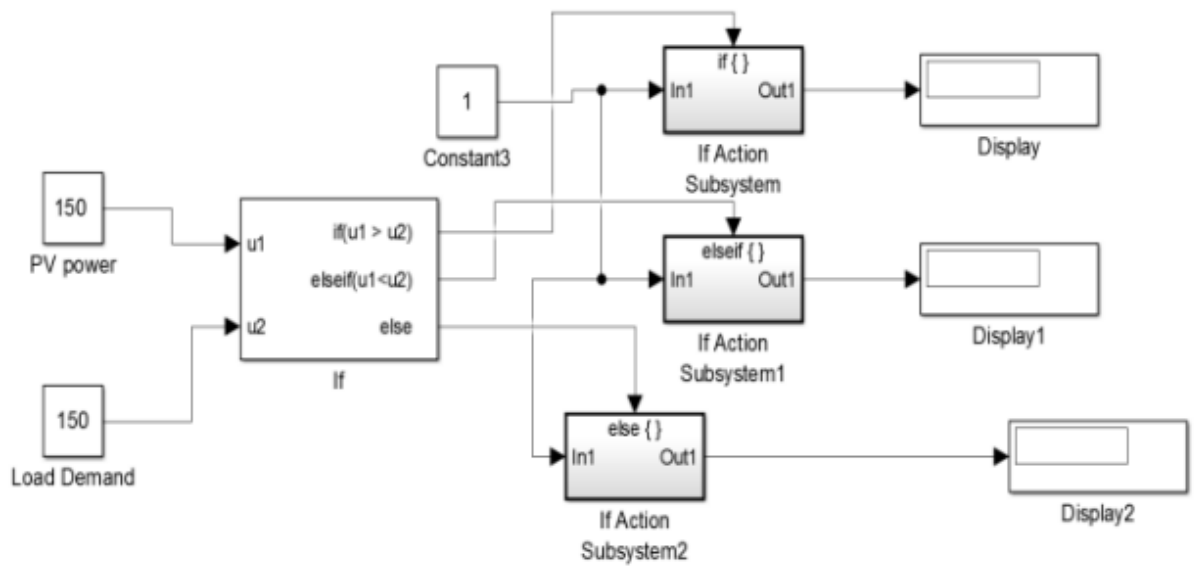

Fig. 6 Controller design for power flow management

\subsection{Operation:}

Mode1: In Figure 7 shown the power of photovoltaic generator $150 \mathrm{~W}$ is greater than load demand $100 \mathrm{~W}$. In this condition the switches SA1 and SB2 ON then SA2 and SB1 OFF. In this model, the power from through Photovoltaic + ve terminal, switch SA1, diode D1, inductance L, diode D2, switch SB2 and finally closed loop with - ve terminal of photovoltaic.

The Power Flow direction: $\mathrm{PV}_{+\mathrm{ve}} \rightarrow \mathrm{SA} 1 \rightarrow \mathrm{D} 1 \rightarrow \mathrm{L} \rightarrow \mathrm{Load}_{\rightarrow} \mathrm{D} 2 \rightarrow \mathrm{SB} 2 \rightarrow \mathrm{PV}_{-\mathrm{ve}}$

In this condition, the mode 1 simulation results are obtained such as load voltage and switching ON- Off waveforms are presented in Figures 8 and 9 respectively.

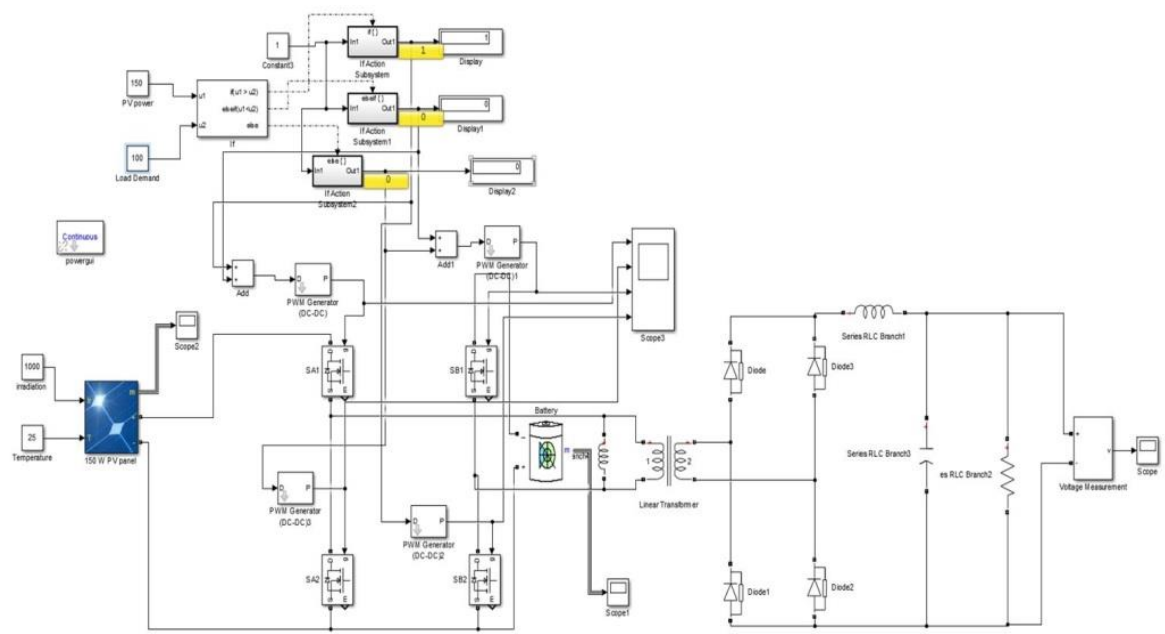

Fig. 7 Three port converter being operated in first mode 


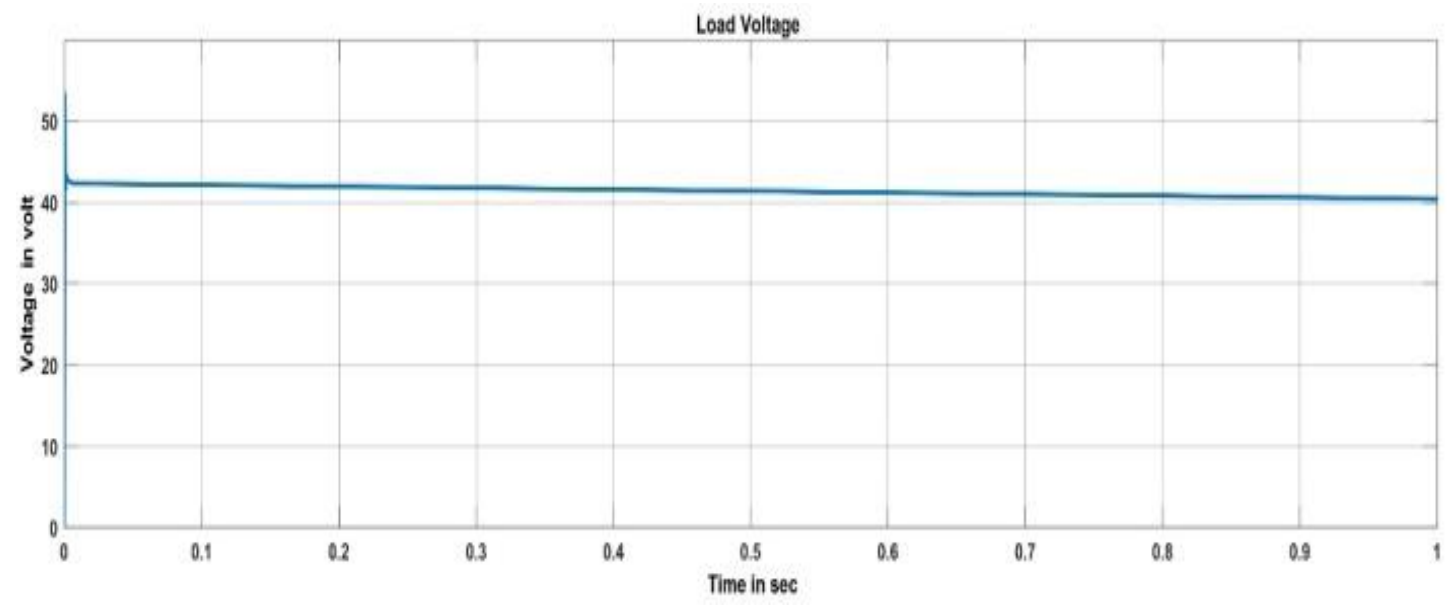

Fig. 8 Mode 1: out put voltage
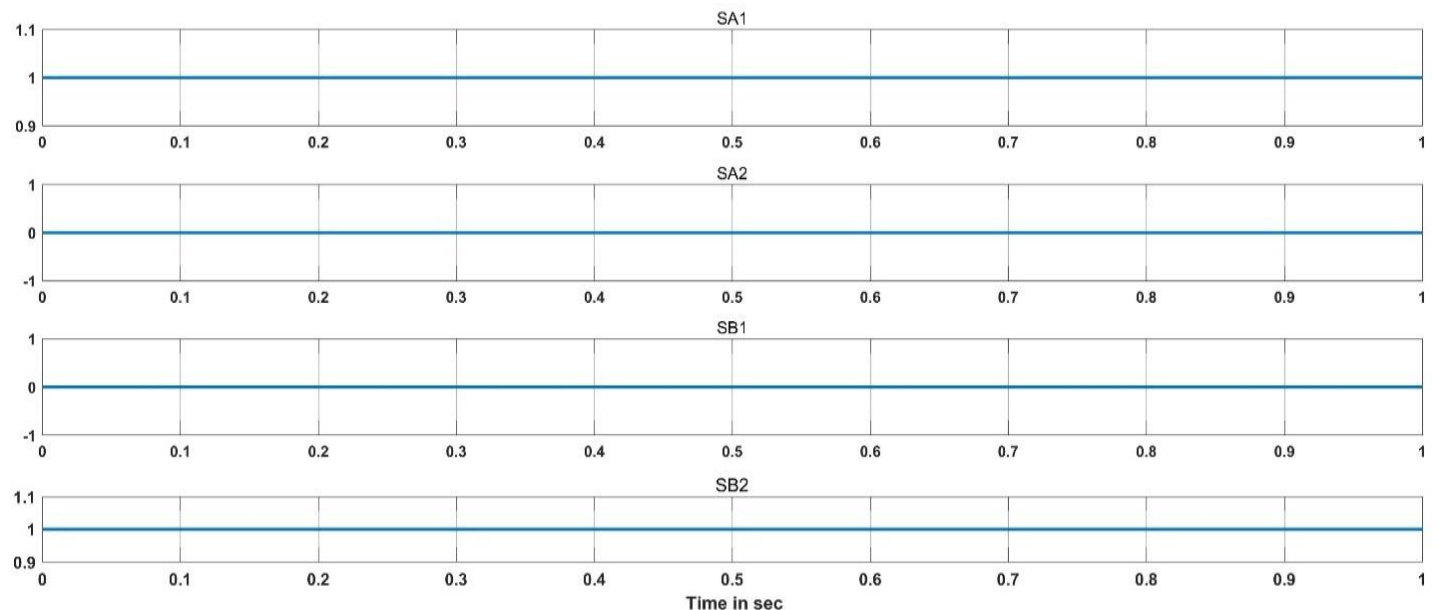

Fig. 9 Mode 1: Switch waveforms

Mode 2: Figure 10 shows the power of photovoltaic generator that is around $150 \mathrm{~W}$ and is lesser than load demand $200 \mathrm{~W}$. In these conditions the SA1 switch and SB1 switch are ON then SA2 switch and SB2 switch are OFF as shown in Figure 12. In this model, the power from through Photovoltaic + ve terminal, switch SA1, diode D1, inductance L, diode D2, switch SB1, battery and finally closed loop with-ve terminal of photovoltaic.

The Power Flow direction: PV + ve $\rightarrow$ SA1 $\rightarrow$ D1 $\rightarrow$ L $\rightarrow$ Load $\rightarrow$ D2 $\rightarrow$ SB $1 \rightarrow \mathrm{V}_{\text {Battery }} \rightarrow$ PV $_{\text {-ve }}$ In this condition the mode 2 simulation results are obtained such as load voltage and switching ON- Off waveforms are presented in Figure 11 and Figure 12 respectively. 


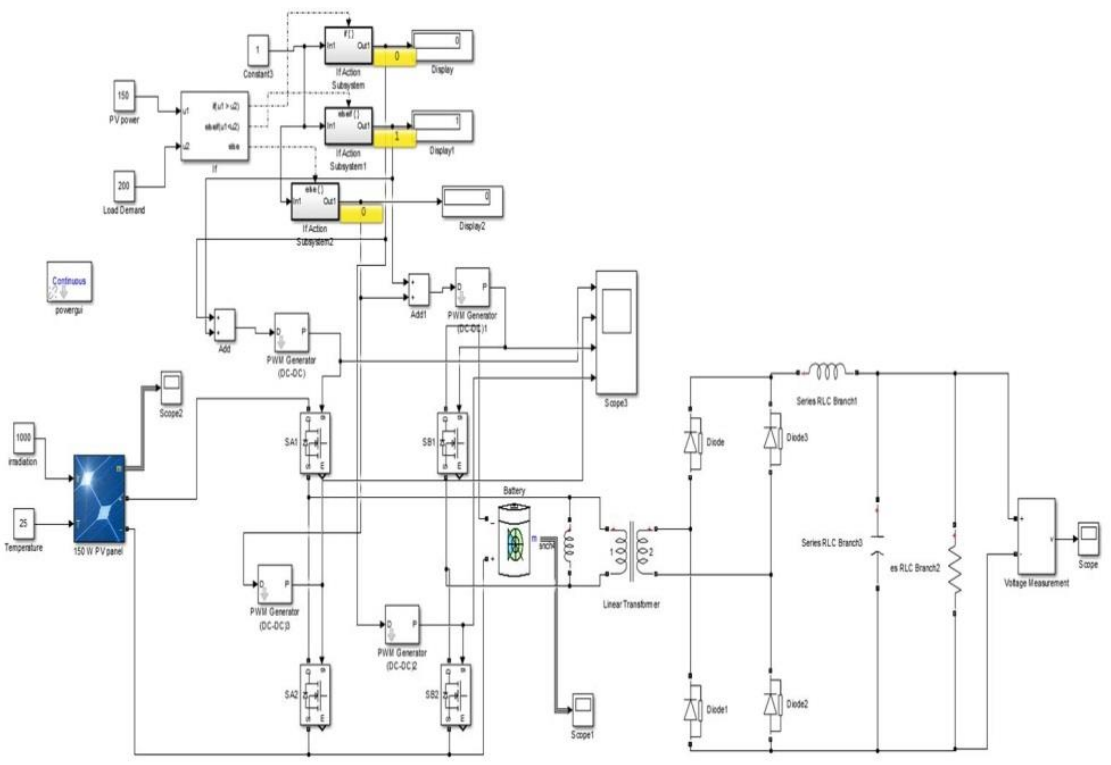

Fig. 10 Three port converter being operated in second mode Load Voltage

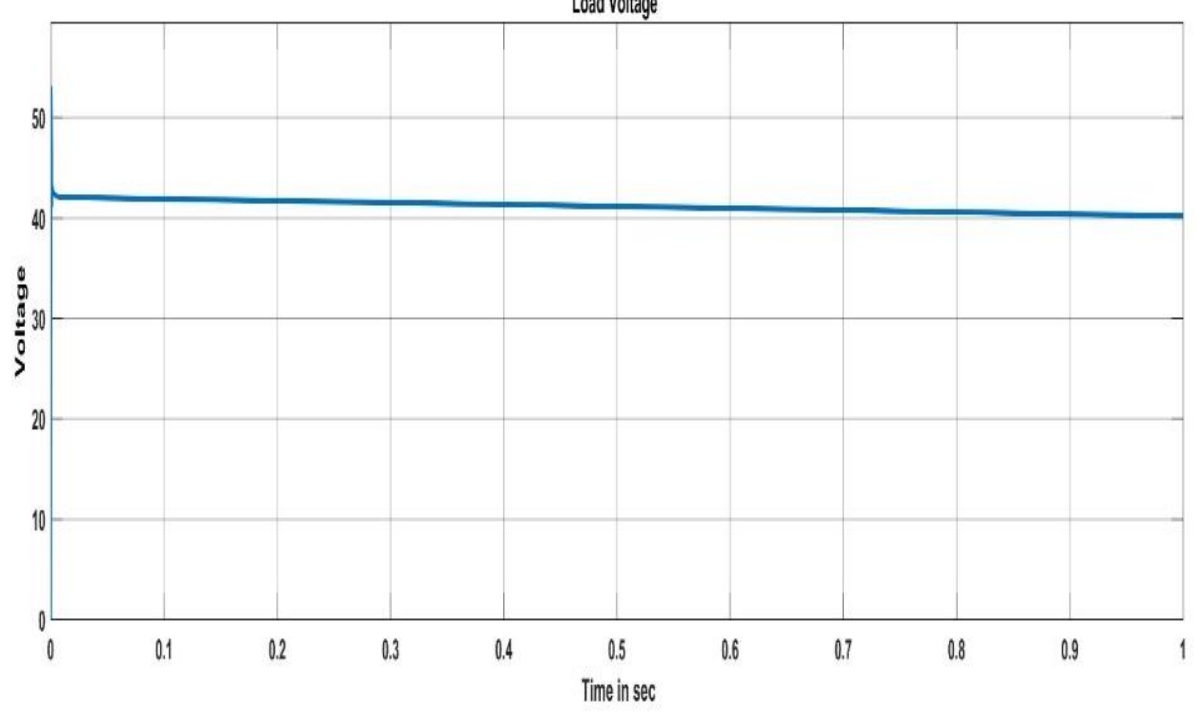

Fig. 11 Mode 2: Output voltage 

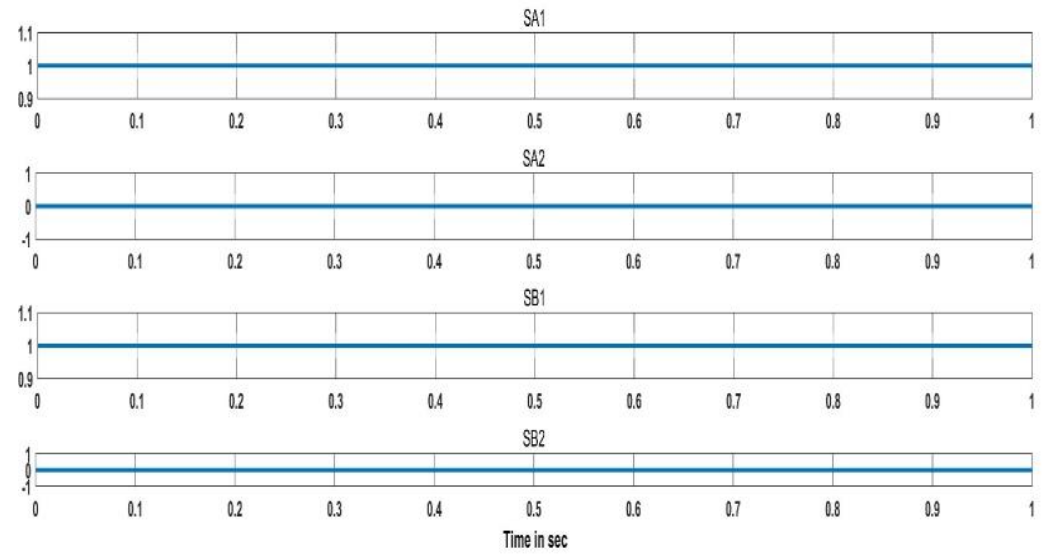

Fig. 12 Mode 2: Switch waveforms

Mode 3: In Figure13 The power of the photovoltaic generator and load demand is equal to 150 W. In this condition the switch SA2 switch and SB1 switch are ON then SA1 switch and SB2 switch are OFF as shown in Fig 15. Moreover, the power from through Battery terminal, switch SB1, diode D3, inductance L, diode D4 and switch SA2, battery

The Power Flow direction: $\mathrm{V}_{\text {Battery }} \rightarrow \mathrm{SB} 1 \rightarrow \mathrm{D} 3 \rightarrow \mathrm{L} \rightarrow$ Load $\rightarrow \mathrm{D} 4 \rightarrow \mathrm{SA} 2$

For this condition, the mode 3 simulated results are obtained such as load voltage and switching ON-Off waveforms are presented in Figure 14 and Figure 15 respectively.

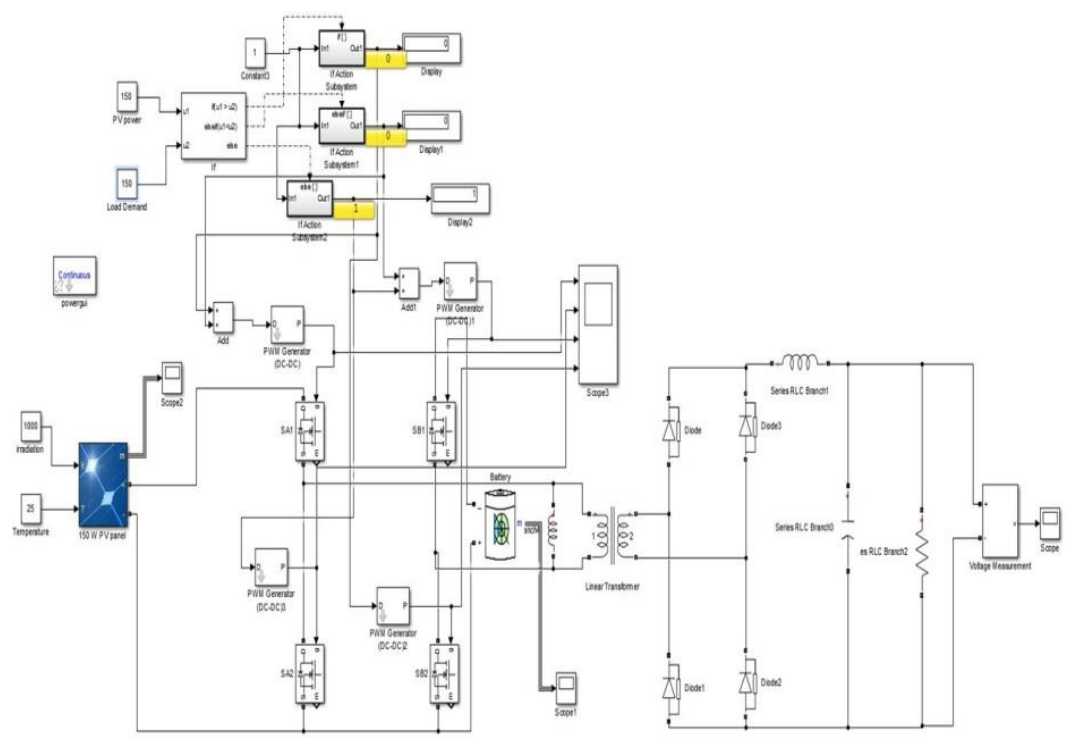

Fig. 13 Three port converter being operated in third mode 


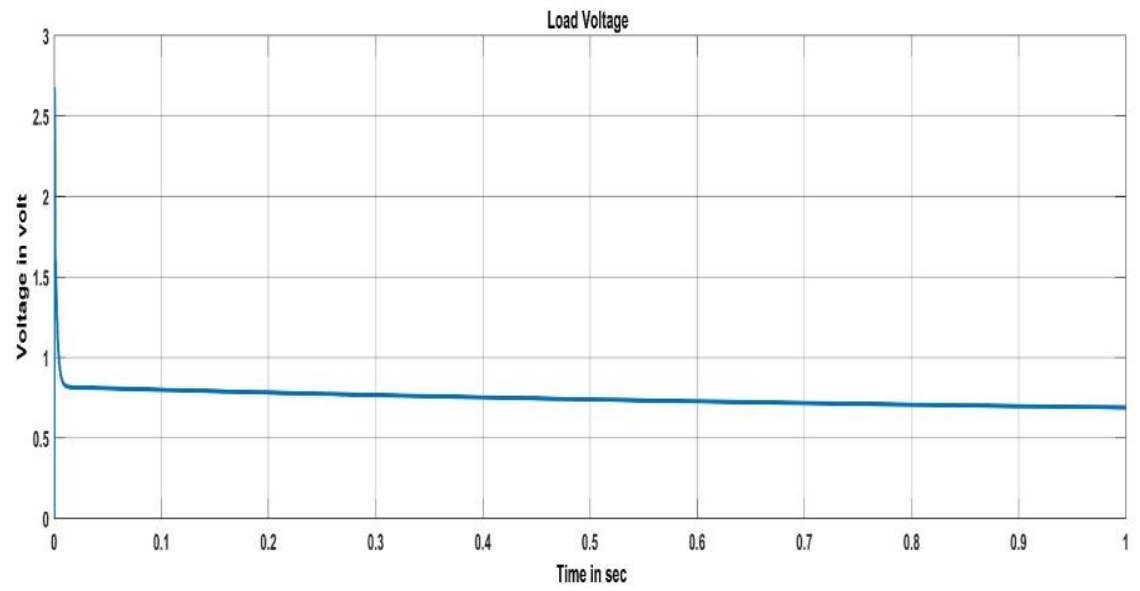

Fig. 14 Mode 3: output voltage
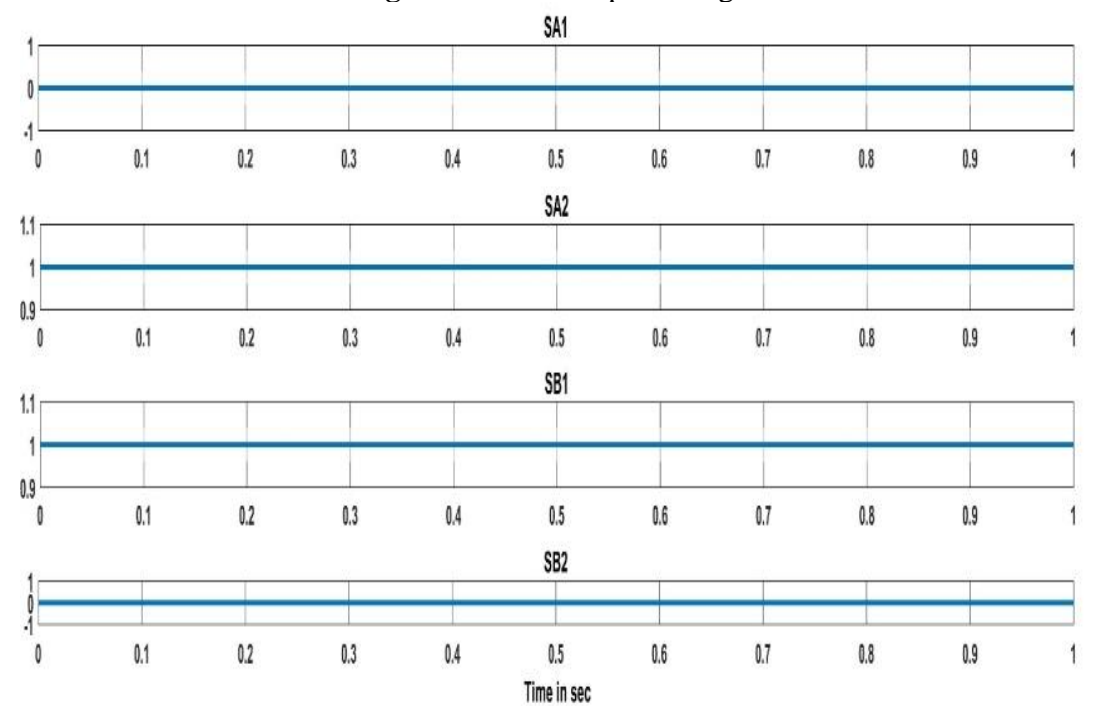

Fig. 15 Mode 3: switch waveformes 


\section{CONCLUSION}

We have analysed a three-port full-bridge converter that uses hybrid sources of PV cells and batteries. We have considered different aspects of PV panels, this converter interfaces the power generated from the PV source with the batteries and the load via an isolation transformer. There are four MOSFET switches present in this converter to manage the flow of power between different ports. A smart controller is integrated into the converter which decides the flow of power depending upon certain conditions such as PV power and the load demand. Based on the decision at any given time, the controller provides waveforms to all the switches. Finally, the power of the results of the photovoltaic generator follows the direction proposed by the MOSFET switcher's control.

\section{References}

[1] AL-CHLAIHAWI, S; CRACIUNESCU, A.: Three port converters used as interface in photovoltaic energy systems. Advances in Science, Technology and Engineering Systems Journal, pp. 263-270 (2018).

[2] Al-Chlaihawi, S et al.: Full bridge three port converter power flow control using fuzzy logic controller. 2017 IEEE International Conference on Environment and Electrical Engineering and 2017 IEEE Industrial and Commercial Power Systems Europe (EEEIC/I\&CPS Europe). IEEE(2017).

[3] Al-Chlaihawi, S. Al-GIZI, A.: A survey of multiport converters used in renewable energy. 2016 International Symposium on Fundamentals of Electrical Engineering (ISFEE), pp. 1-4 (2016).

[4] Al-Chlaihawi, S.: Comparative study of the multiport converter used in renewable energy systems. 2016 International Conference on Applied and Theoretical Electricity (ICATE), IEEE, pp. 1-6 (2016). [5] AL-Chlaihawi, S., Craciunescu, A., and Al-Gizi, A.: Power flow management in three port converter using PV panel with maximum power point tracker. 10th International Symposium on Advanced Topics in Electrical Engineering (ATEE), IEEE, pp. 585-590 (2017).

[6] Anandhakumar, G. Venkateshkumar M. and Shankar P.: Intelligent controller based MPPT method for the Photovoltaic power system. Human Computer Interactions (ICHCI). International Conference on, Chennai, pp. 1-6 (2013).

[7] Al-Gizi, A. Craciunescu, A. and Al-Chlaihawi, S.: Improving the performance of PV system using genetically-tuned FLC based MPPT. International Conference on Optimization of Electrical and Electronic Equipment (OPTIM) \& 2017 Intl Aegean Conference on Electrical Machines and Power Electronics (ACEMP), IEEE, pp. 642-647(2017).

[8] Falcones, S. Ayyanar R. and Mao, X.: A DC-DC Multiport-Converter-Based Solid-State Transformer Integrating Distributed Generation and Storage, IEEE, pp. 2192-2203 (2013).

[9] Wu H. Et al.: Multiport Converters Based on Integration of Full-Bridge and Bidirectional DC-DC Topologies for Renewable Generation Systems, IEEE, pp. 856-869 (2014).

[10] Tran, Y. Dujić, D. and Barrade , P.: Multiport resonant DC-DC converter. IEEE. pp. 003839003844 (2015).

[11] Ammar, A.: Experimental installation of photovoltaic MPPT controller using Arduino board. International Conference on Applied and Theoretical Electricity (ICATE). IEEE. pp. 1-6 (2018)

[12] Al-Gizi, A., Al-Chlaihawi, S., and Craciunescu, A.: Efficiency of photovoltaic maximum power point tracking controller Based on a fuzzy logic. Advances in Science, Technology and Engineering Systems Journal (ASTESJ). pp. 1245-1251 (2017).

[13] Al-Gizi, A. et al.: Genetically optimization of an asymmetrical fuzzy logic based photovoltaic maximum power point tracking controller. Advances in Electrical and Computer Engineering. pp. 6976 (2017).

[14] Al-Gizi, A. et al.: The use of ANN to supervise the PV MPPT based on FLC. 10th International Symposium on Advanced Topics in Electrical Engineering (ATEE), IEEE,pp. 703-708 (2017). 